\title{
Inclusion of the FuzzyILS Method in MOODLE for Creating Effective Courses
}

\author{
Antonio Silva Sprock \\ Universidad Central de Venezuela, Caracas, Venezuela \\ https://orcid.org/0000-0002-9911-4774
}

\begin{abstract}
The work exposes the analysis of the effectiveness of courses in MOODLE when the course is developed with activities according to the learning styles of the students which have been determined using the FuzzyILS Method. The investigator has adapted the FuzzyILS method and designed the FuzzyILS questionnaire based on former attempts and the researcher's observations to calculate the degrees of belonging of the fuzzy sets, and evaluate the activities of MOODLE, according to the learning styles of students. The investigator has used the experimental research with forty students from the Central University of Venezuela grouped into two groups, namely the experimental group and the control group with twenty students each. The results show evidence of improvement in learning and reflect greater participation in the proposed activities when the FuzzyILS Method and MOODLE techniques are used with the learning styles of students.
\end{abstract}

Keywords: FuzzyILS Method; Learning Styles; Fuzzy Sets; MOODLE

\section{Introduction}

Information and Communication Technologies (ICT) continue to advance in education and makes it possible to extend teaching and learning environments. Its enrichment permits the development of collaborative and interactive virtual environments, with the use of different didactic materials, such as presentations, multimedia elements, intelligent tutors, among others. The use of ICT has also allowed the creation of new educational models, related to distance education, such as E-Learning, Blended-Learning, and Mobile-Learning (Dorfsmani, 2012). Distance education is advancing, not only as an alternative in 2020, but also it becomes the only option in the face of the COVID-19 pandemic. That is to say, the new situation leads to new challenges to take place: to navigate the pandemic by maintaining classes without overloading the different actors mainly in finding ways to establish a pedagogical link remotely, and be attentive to all that is happening around this context (Artopoulos, 2020). Many tools favour the virtual environments in e-learning, part of these are the Learning 
Management Platforms (Learning Management Systems or simply LMS), for example, MOODLE.

On the other hand, students, regardless of the learning environment, they structure their strategy for learning depending on their learning style, they use in a conscious, controlled, and intentional way, procedures (set of steps, operations, or skills) to learn and solve problems (Díaz-Barriga \& Hernández, 2010). Its effectiveness depends to a great extent on the instructional strategy used by the teacher (Ossandón \& Castillo, 2006). Therefore, learning styles represent a determining factor of the teaching and learning process (Paredes, 2008). Felder \& Silverman (1988) for example, argue that students with a strong preference for a learning style may have difficulties in the process if the teaching environment is not adapted to their learning style. In this concern, students learn and perform better if the learning environment includes activities in which they participate and apply knowledge, rather than being passive in the process and simply listening (Prince, 2013; Freeman, Eddya, McDonougha, Smithb, Okoroafora, Jordta \& Pat Wenderotha, 2014), bearing in mind the fact that the effectiveness of a technique is related to the expected result when performing tests that measure the level of knowledge of the student about the knowledge imparted (Lozano, Suescún, Vallejo, Mazo \& Correa, 2020).

This study aims to analyze the effectiveness of a course MOODLE, using the techniques appropriate to the students learning styles being determined by the FuzzyILS Method, which broke with the dichotomy of the Index of Learning Styles Questionnaire (ILS) of Felder and Soloman (2007).

\section{Literature Review}

This section is meant to review the relevant concepts and elements related to this study. First, it begins with the MOODLE issue, the learning styles concept, the correlation among MOODLE and learning styles, and the FuzzyILS Method.

\subsection{MOODLE}

The modular object-oriented dynamic learning environment (MOODLE) is a learning management platform (Learning Management Systems or simply LMS) where teachers can build courses using templates for contents developments, among them forums, chat, quizzes, glossaries, workshops, surveys, and exercises type multiple-choice, true/false, and one-word answers. The services provided generally include access control, educational content development, communication tools, and administration of student groups. The LMS has numerous advantages in the field of distance education, especially in creating a student-teacher link which translates into educational and professional success (Díaz, 2009; Boneu, 2007). The LMS favours communication and interaction between the students of the subject and the teacher who dictates it. These tools overcome the barrier of shyness and favored the interaction and bonding among students. Such a fact generates collaborative work to occur (Silva \& Vicari, 2016). 
For this, MOODLE offers multiple activities and tools (Moodle, 2020):

- Chat: Allows participants to have a real-time synchronous discussion

- Choice: A teacher asks a question and specifies a choice of multiple responses

- Forum: Allows participants to have asynchronous discussions

- Glossary: Enables participants to create and maintain a list of definitions, like a dictionary

- Lesson: For delivering content in flexible ways

- Survey: For gathering data from students to help teachers learn about their class and reflect on their teaching

- Wiki: A collection of web pages that anyone can add to or edit

- Workshop: Enables peer assessment.

These functionalities support flexible and active learning under the constructivist approach (Cabero-Almenara, Arancibia \& Del Prete, 2019), and the teachers have much freedom concerning the format of the content they can create in MOODLE. They have access to a wider variety than when using traditional handouts (Szirmai, 2020); however they do not assist the teacher in the construction of the courses as it is often a challenge for a teacher to successfully structure courses and activities in the LMS (Silva, Ponce \& Meneses, 2013). This happens because they must prepare the contents and the instructional activities and direct the learning. This process is efficient only when teachers consider the characteristics of the students and the previously established instructional objectives. These students' characteristics include their profiles, and MOODLE is pedagogically neutral for it does not consider student profiles to structure the courses (Almeida, Romero \& Arce, 2017). Then this is a deficiency of MOODLE because the instructional techniques must have different degrees of adequacy and effectiveness in the teaching and learning process. This effectiveness calls forstudents' learning styles (Silva, Ponce \& Meneses, 2013).

\subsection{The Learning Styles}

There are multiple conceptions of learning styles (Silva, 2018), among them the one proposed by James Keefe (1987), who defines them as "cognitive, affective, physiological traits, preferences for the use of the senses, environment, culture, behavior, comfort, development and personality, which serve as relatively stable indicators, of how people perceive, interrelate and respond to their learning environments and their methods or strategies in their way of learning" (Keefe, 1987). The importance of knowing learning styles is helpful mainly in adapting the way of teaching to each student's style, improving education, and making education more effective (Silva, 2018). The current research paper is based on the Felder and Silverman Learning Styles Model (FSLSM) (Felder \& Silverman, 1988), since it is considered to be the most used in technologies and sciences students.

\subsection{MOODLE and Learning Style}

Regarding MOODLE, two ways in incorporating learning styles in the LMS have been proposed. Firstly, some authors added learning styles questionnaire to MOODLE, such as the CHAEA questionnaire being associated with the Kolb Model (Torres, Molina \& Álvarez, 2010; Lavigne, Díaz, McAnally \& Organista, 2013; Rubio, 2009; Pacheco, Miranda \& Alonso, 2020); others (Peña, Mendoza \& 
González, 2015; Puello, Fernández \& Cabarcas, 2014; Graf \& Kinshuk, 2007; Graf, Kinshuk \& Liu, 2008; Mohd, Yahya, Ismail, Jalil \& Noor, 2019) associate it with the ILS (Felder \& Soloman, 2007), while some others assimilate it with the Myers and Briggs model (Bignetti \& Jasbinschek, 2011).

The second way concerned its association with FSLSM (Felder \& Silverman, 1988) which has been studied by Despotović-Zrakić, Marković, Bogdanović, Barać and Krčo (2012) and more recently with Karagiannis and Satratzemi (2018) study. In fact, Rubio (2009) incorporated a learning styles module based on the CHAEA questionnaire in MOODLE, which was called LSTest. Subsequently, Puello, Fernandez and Cabarcas (2014) modified the LSTest and incorporated the Index Learning styles ILS (Felder \& Soloman, 2007) to this LSTest. Both attempts serve as the basis for this proposal. In addition to these works, the study by Despotović, Marković, Bogdanović, Barać and Krčo (2012) shows the relationship between MOODLE activities and tools with the learning styles of FSLSM (Felder \& Silverman, 1988), where they assigned "Yes", "No" or "Shortly" as indexes to display the adequacy of the MOODLE activities with the learning styles. Table 1 shows this relation.

Table 1: The relationship of MOODLE activities with the learning styles (Despotović et al., 2012).

\begin{tabular}{|l|c|c|c|c|c|c|c|c|}
\hline MOODLE & \multicolumn{7}{|c|}{ FSLSM Dimensions } \\
\cline { 2 - 9 } Activities & Sens. & Intui. & Visual & Verb. & Sec. & Glob. & Act. & Refl. \\
\hline Forum & Yes & Yes & No & Yes & Yes & Yes & Yes & Yes \\
\hline Chat & Yes & No & No & Yes & Yes & No & Yes & No \\
\hline Glossary & Yes & No & No & Yes & Yes & No & Yes & Yes \\
\hline Workshop & Yes & Yes & Yes & Yes & Yes & Yes & Yes & Yes \\
\hline Survey & Yes & Yes & Yes & Yes & No & Yes & No & Yes \\
\hline Choice & Yes & No & Yes & Yes & Yes & Shortly & Yes & Yes \\
\hline Lesson & Yes & Shortly & Yes & Yes & Yes & Shortly & Yes & Yes \\
\hline Wiki & No & Yes & No & Yes & Yes & No & Yes & Shortly \\
\hline
\end{tabular}

\subsection{The FuzzyILS Method}

The FuzzyILS Method (Silva, 2020) is a system to evaluate the learning styles using a fuzzy questionnaire (Appendix), based on the FSLMS (Felder \& Silverman, 1988) and as an alternative fuzzy to ILS (Felder \& Soloman, 2007). The FSLSM (Felder \& Silverman, 1988) considers four dimensions of learning styles, wherein each dimension is dichotomous having two extremes, these are: Active/Reflective, Sensing/Intuitive, Visual/Verbal, and Sequential/Global. After, Felder and Soloman (2007) developed the ILS, related to FSLSM, to determine the learning styles. The ILS has forty-four questions, while each dimension of the FSLSM covers eleven questions. Each one has two possible answers, in which each answer corresponds with one of the extremes of the dimension. For example, in the Visual/Verbal "I prefer to read" meets the Visual extreme and "I prefer to hear" for Verbal extreme.

With the ILS, Silva, Ponce \& Villalpando (2013, 2014, 2014a), created the MeLOTS method for the development of Learning Objects based on instructional techniques and learning styles, where they relate thirty-one 
instructional techniques to the dimensions of the FSLSM. This method is evaluated with students and their opinions as key foundations for the development of the FuzzyILS Method. In this respect, students indicated that some answers or options of the questions should not be exclusive. They said that the dichotomy cannot exist in some questions and that they wish that some of their answers were intermediate (Silva, Ponce \& Villalpando, 2015). The same conception is also found by Cataldi, Figueroa, Méndez, Lage, Vigliecca and Kraus (2006).

Taking the abovesaid into consideration, Silva (2020) shows a way to break this dichotomy. The solution included the notion of intermediate answers what have different degrees of belonging to the sets associated with the four dimensions, wherein these degrees are calculated with fuzzy logic (Zadeh, 1965). In this sense, the author proposed the fuzzy sets as an extension of the ILS dichotomous sets which have been further developed and evaluated. Thus, unlike the original ILS put forward by Felder and Soloman (2007), each question has five options. The following is an example that is used to display how the options are organised, established, and how the values are distributed for each answer.

Question 1, associated with the Active/Reflective dimension, "I understand something better after:"

a. Always practice

b. Almost always practice, and rarely reflect on them

c. Sometimes practice, and sometimes reflect on them

d. Almost always reflect on them, and rarely practice

e. Always reflect on them

Each option is value with fuzzy sets shown in Figure 1. The values of each answer using these fuzzy sets are displayed in Table 2.

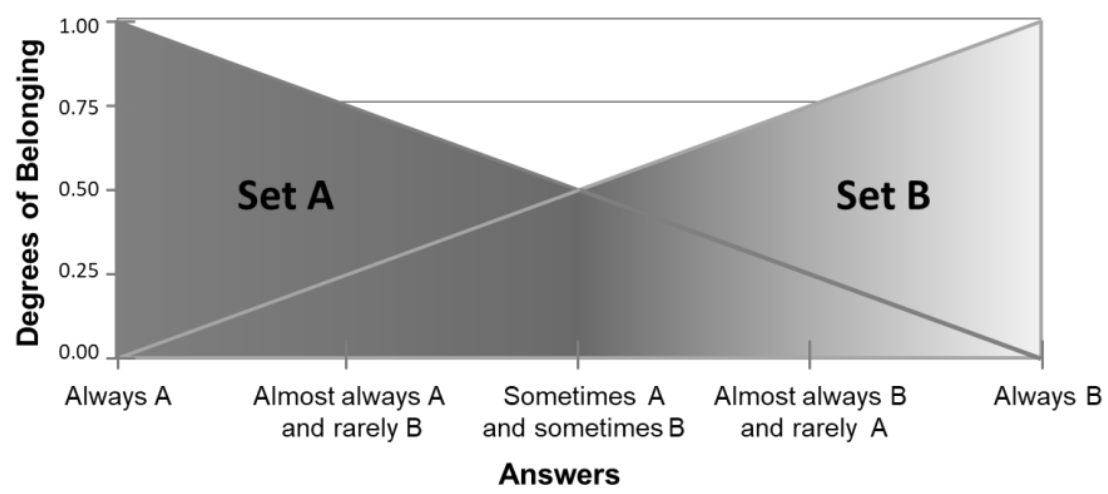

Figure 1: Fuzzy sets used to establish the values of the FuzzyILS Questionnaire answers

Table 2 shows the different values possible for the first answer in the FuzzyILS Questionnaire. 
Table 2: Values each answer using the fuzzy sets for the first question in the FuzzyILS Questionnaire

\begin{tabular}{|l|c|c|}
\hline \multicolumn{1}{|c|}{ Answer } & Active & Reflective \\
\hline a) Always practice & 1 & 0 \\
\hline b) Almost always practice, and rarely reflect on them & 0.75 & 0.25 \\
\hline c) Sometimes practice, and sometimes reflect on them & 0.50 & 0.50 \\
\hline d) Almost always reflect on them, and rarely practice & 0.25 & 0.75 \\
\hline e) Always reflect on them & 0 & 1 \\
\hline
\end{tabular}

With the value of each question, FuzzyILS Method adds all values for each dimension. Table 3 shows the possible values for all questions in the Active/Reflective dimension.

Table 3. Possible values for each question for the Active/Reflective dimension.

\begin{tabular}{|c|c|c|}
\hline Questions & Active & Reflective \\
\hline 1 & 0.75 & 0.25 \\
\hline 5 & 0.5 & 0.5 \\
\hline 9 & 0.75 & 0.25 \\
\hline 13 & 0.25 & 0.75 \\
\hline 17 & 0.25 & 0.75 \\
\hline 21 & 0.5 & 0.5 \\
\hline 25 & 0.75 & 0.25 \\
\hline 29 & 0.25 & 0.75 \\
\hline 33 & 0.75 & 0.25 \\
\hline 37 & 0.5 & 0.5 \\
\hline 41 & 0.25 & 0.75 \\
\hline Total & $\mathbf{5 . 5}$ & $\mathbf{5 . 5}$ \\
\hline
\end{tabular}

After calculating the total value of each dimension, manipulating the degree of belonging of each dimension is shown in the following figure.

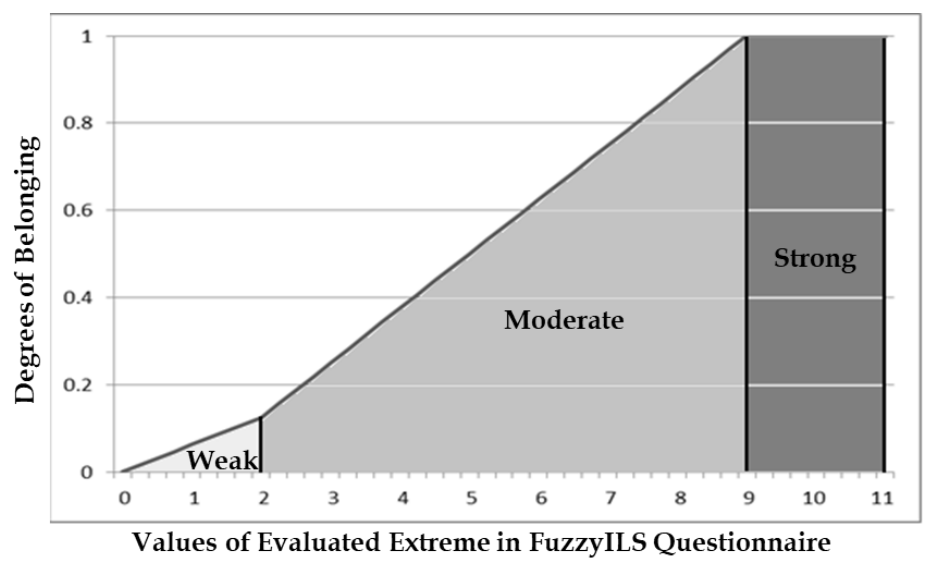

Figure 2: Fuzzy sets to evaluate the dimensions of the FSLSM in the FuzzyILS Method 
These fuzzy sets make Equation 1 for displaying the sets (Weak, Moderate, and Strong) and the formulas for each interval in which $\mathrm{X}$ reflects the total value of the dimension.

$$
\mu(x)\left\{\begin{array}{lll}
\frac{1}{16} \mathrm{X} & 0 \leq x<2 & \text { Weak degree } \\
\frac{1}{8} \mathrm{X}-\frac{1}{8} & 2 \leq x<9 & \text { Moderate degree } \\
1 & 9 \leq x \leq 11 & \text { Strong degree }
\end{array}\right.
$$

With the degree of belonging, the learning styles are clearly obtained. For example, the value in table 3 (Active $=5.5$ and Reflective $=5.5$ ), corresponds with the second interval in Equation 1, and the degree of belonging is 0.56 for Active and reflective, and both values are in the Moderate set. Integrating the FuzzyILS Method with MOODLE to associate the LMS activities to the learning styles is the main concern in this research work. In any course development platform, one can integrate it as a move to relate instructional techniques with students' learning styles (Silva, Ponce \& Villalpando, 2014) in hope to offer support to the teachers for effective and appropriate courses.

\section{Methodology}

This section discusses the objective of the study, the incorporation of the FuzzyILS Method in MOODLE, the sample of the study, and the experimentation with this sample.

\subsection{Objective}

As indicated at the beginning, the main objective of the study is to analyze the effectiveness of a MOODLE course taking into consideration students' learning styles being determined by the FuzzyILS Method. To validate its effectiveness, the researcher evaluates students' participation in the MOODLE activities by considering grade they obtain in a content evaluation test. The idea that if a student participates actively in the activities, he will learn better, as indicated by other authors (Prince, 2013; Freeman et al., 2014) is the standing conception the researcher used. On the other hand, the investigator based the evaluation of the qualification on the fact that the effectiveness of a technique is related to the expected result when performing tests that measure the student's level of knowledge about the knowledge imparted (Lozano, et al., 2020). First, the FuzzyILS Method in MOODLE is integrated, then the questionnaire is added along with the fuzzy sets, values of degree of belonging, and the evaluation of MOODLE activities associated with values of learning styles. All these steps combine to validate the MOODLE course.

\subsection{FuzzyILS Method in MOODLE}

The incorporation phase of the FuzzyILS Method in MOODLE takes some stages that are summarised as follows. 


\subsubsection{LSTest adaptation}

As indicated, previous works were analysed to incorporate the FuzzyILS Method into MOODLE. In the first instance, the learning styles module (LSTest) was downloaded for MOODLE (Rubio, 2009), from the site http://innova.cicei.com/course/view.php?id=24, which consist of the programs, tables of the Database, and files to be incorporated to the LMS. Subsequently, the elements of the Module were modified, considering other work (Puello, Fernández \& Cabarcas, 2014). Figure 3 shows the components of the LSTest Module, where modifications made by Puello and colleagues are reflected in light gray and the investigator's modifications are displayed in dark gray.
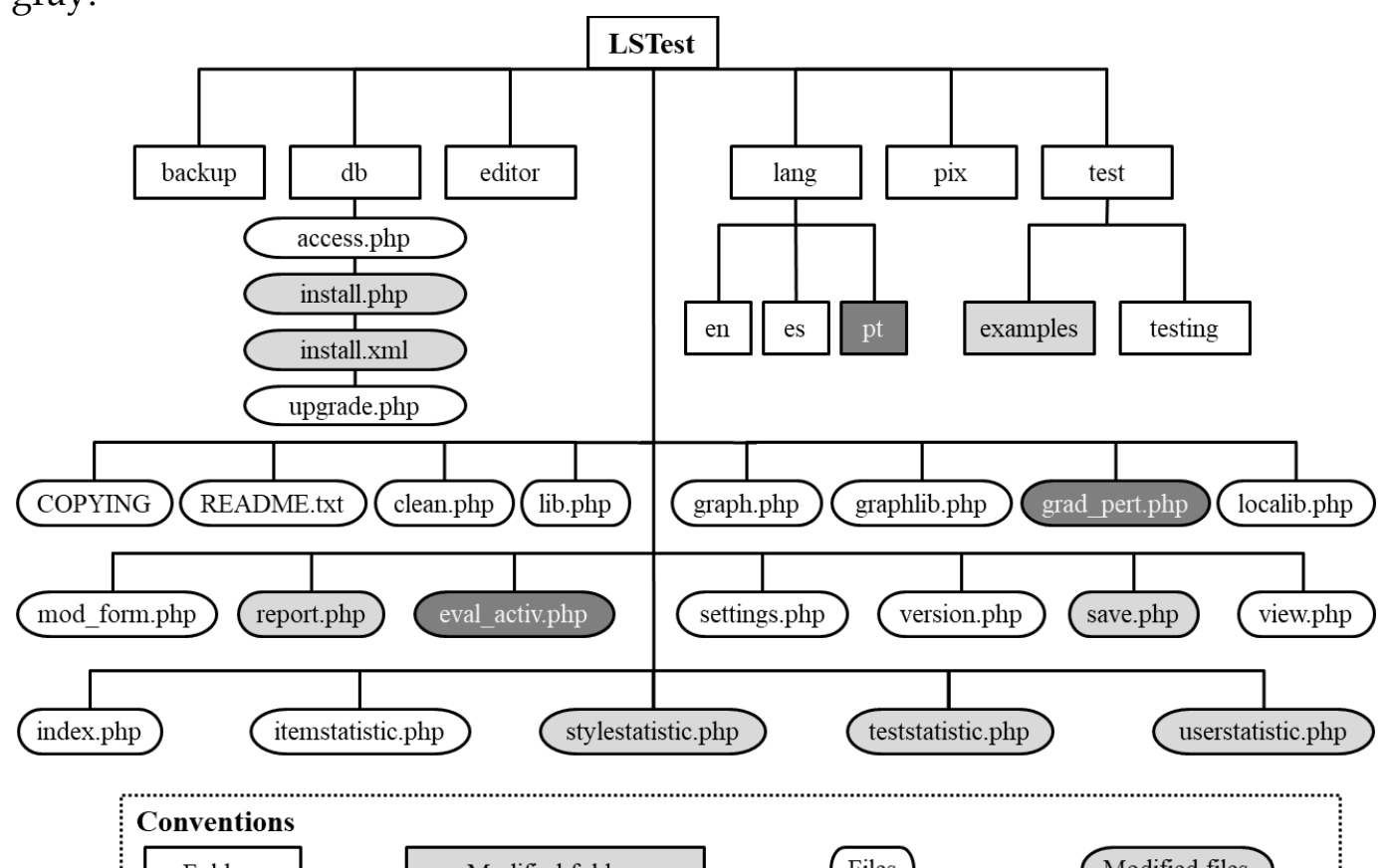

Folders

Modified folders

Figure 3: LSTest module (adaptation of Puello, Fernández \& Cabarcas, 2014)

Puello, Fernández and Cabarcas (2014) did modifications which are described below:

1. In the test folder $->$ examples, they added the ILS.

2. They modified the install.php and install.xml files to add the changes and optimize the module installation with the ILS.

3. They added and modified several functions in the localib.php file, the file where the working logic of the Test and the reports of the Module.

4. In the save.php file, they incorporated functions to store the results of the ILS.

5. They modified the report.php file to present the results of the ILS on a worksheet per student per course.

6. They also modified the stylestatistic.php, teststatistic.php, and userstatistic.php files to present the results' tables and the statistics according to ILS. 


\subsubsection{Inclusion of FuzzyILS Questionnaire}

The FuzzyILS Questionnaire is added in the test folder, wherein Figure 4 shows the Test interface of MOODLE.

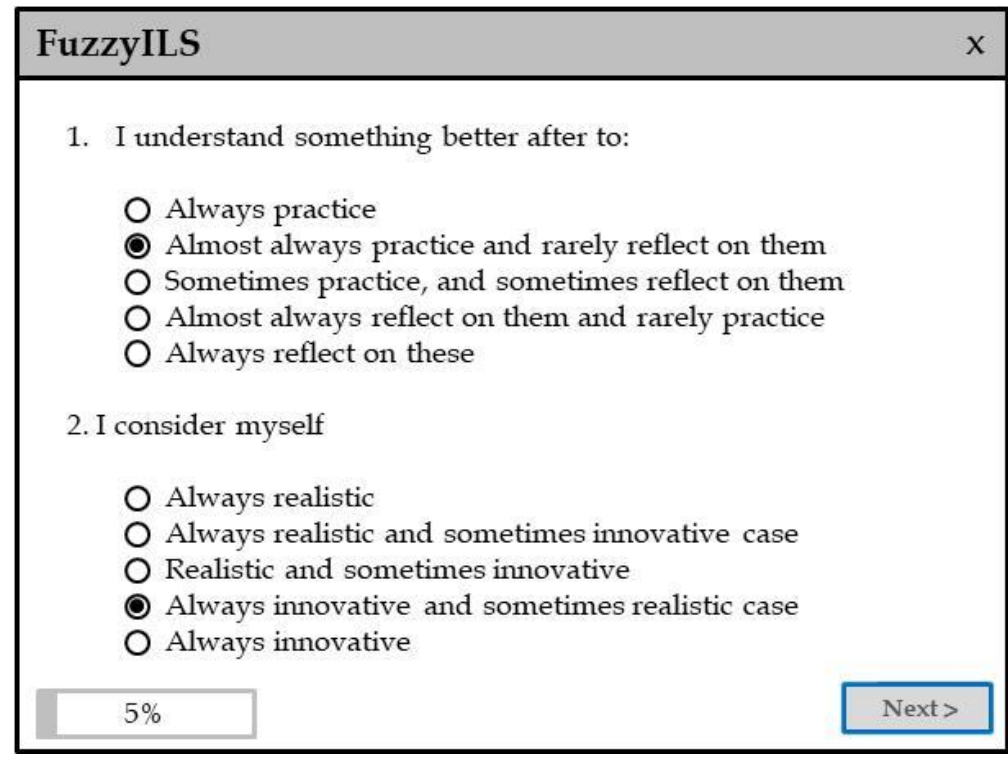

Figure 4: FuzzyILS Questionnaire interface

\subsubsection{FuzzyILS Questionnaire in Portuguese.}

The researcher incorporated the Portuguese into the MOODLE being developed in the lang folder $->$ pt. Figure 5 shows the Test interface in Portuguese.

\begin{tabular}{|l}
\hline FuzzyILS \\
\hline 1. Eu compreendo melhor alguma coisa depois de: \\
O Sempre experimentar \\
O Quase sempre experimentar e algumas vezes refletir sobre elas \\
O Experimentar e outras vezes refletir sobre elas \\
O Quase sempre refletir sobre elas e algumas experimentar \\
O Sempre refletir sobre elas
\end{tabular}

2. Eu me considero:

Sempre realista

Quase sempre realista e algumas vezes inovador

O Realista e outas vezes inovador

O Quase sempre inovador e algumas vezes realista

O Sempre inovador

Figure 5: The interface of the FuzzyILS Questionnaire in Portuguese

\subsubsection{Fuzzy Sets to Establish the Values of the FuzzyILS Answers}

Actually, some functions are inserted and the localib.php file is modified to incorporate the fuzzy sets as shown in Figure 1. These modifications were used to modify the Questionnaire logic and Module reports. 


\subsubsection{Degrees of Belonging to Each Dimension}

As an endeavour, the grad_pert.php file is included to develop the logic of evaluation of the degrees of membership of the dimensions, according to Equation 1 and Figure 2so that students' learning styles could be get.

\subsubsection{Evaluation of MOODLE Activities}

The file eval_activ.php is a fixed, where the researcher incorporates the adaptation of Table 1 and change the "yes" value by numeric valor 2, the "no" value by numeric value 0 , and the "shorter" value by 1 . Table 4 shows the adaption made.

Table 4: Valuation of MOODLE in each learning style

\begin{tabular}{|l|c|c|c|c|c|c|c|c|}
\hline \multirow{2}{*}{$\begin{array}{c}\text { MOODLE } \\
\text { Activities }\end{array}$} & Sens. & Intui. & Visual & Verb. & Sec. & Glob. & Act. & Refl. \\
\hline Forum & 2 & 2 & 0 & 2 & 2 & 2 & 2 & 2 \\
\hline Chat & 2 & 0 & 0 & 2 & 2 & 0 & 2 & 0 \\
\hline Glossary & 2 & 0 & 0 & 2 & 2 & 0 & 2 & 2 \\
\hline Workshop & 2 & 2 & 2 & 2 & 2 & 2 & 2 & 2 \\
\hline Survey & 2 & 2 & 2 & 2 & 0 & 2 & 0 & 2 \\
\hline Choice & 2 & 0 & 2 & 2 & 2 & 1 & 2 & 2 \\
\hline Lesson & 2 & 1 & 2 & 2 & 2 & 1 & 2 & 2 \\
\hline Wiki & 0 & 2 & 0 & 2 & 2 & 0 & 2 & 1 \\
\hline \multicolumn{7}{|c|}{} \\
\hline
\end{tabular}

With the valuation shown in Table 4 and the evaluation of the learning styles of each student, then Equation 2 is formulated. For each technique, we need to multiply the value with each student's learning style, where:

$$
t_{i}=\sum_{K=1}^{8} \sigma\left(t_{i}, e_{k}\right) * \mu(k)
$$

1. $t_{i}$ is each MOODLE technique

2. $\sigma$ is the dimension value in the technique $i$ (Table 4 )

3. $\mu$ is the evaluation of dimension in the students (described in 3.2.5 and associated with Figure 2)

For example, the values of the dimensions for a student are as follows:

1. Sensing $=0.69 ;$ Intuitive $=0.44$

2. Visual $=1$; Verbal $=0$

3. Sequential $=0.94 ;$ Global $=0.19$

4. Active $=0.56$; Reflective $=0.56$

Thus, with Equation 2, it is possible to evaluate the Moodle activities. For example, the evaluation of Forum activity is shown in Table 5.

Table 5: Evaluation of the Forum activity in each FSLSM dimensions.

\begin{tabular}{|l|c|c|c|c|c|c|c|c|c|}
\hline MOODLE & \multicolumn{7}{|c|}{ FSLSM Dimensions } \\
\cline { 2 - 9 } Activities & Sens. & Intui. & Visual & Verb. & Seq. & Glob. & Act. & Refl. & Tot. \\
\hline Forum & $2^{*} 0.69$ & $2^{*} 0.44$ & $0^{*} 1.00$ & $2^{*} 0.00$ & $2^{*} 0.94$ & $2^{*} 0.19$ & $2^{*} 0.56$ & $2^{*} 0.56$ & 8.07 \\
\hline
\end{tabular}




\subsection{The sample}

A sample of forty students of an introductory computer course are used in this research work by dividing them into two groups (experimental and control group). Both groups took a mini Unified Modeling Language (UML) course structured in MOODLE. The experimental group used the MOODLE with FuzzyILS Method whereas the control group took the original MOODLE without FuzzyILS Method. The intention is to validate that a MOODLE course structured with techniques associated with the learning styles of the students is an effective course, and the students get better results than a course with techniques not associated with Learning styles.

\subsection{The evaluation of learning styles of the experimental group}

Table 6 shows the result of the responses of the twenty students of the experimental group.

Table 6: Evaluation of learning styles dimensions using the FuzzyILS Questionnaire

\begin{tabular}{|c|c|c|c|c|c|c|c|c|}
\hline Students & Sens. & Int. & Visual & Verb. & Seq. & Glob. & Act. & Refl. \\
\hline 1 & 6.5 & 4.5 & 10 & 1 & 8.5 & 2.5 & 5.5 & 5.5 \\
\hline 2 & 2.5 & 8.5 & 8.5 & 2.5 & 10 & 1 & 4 & 7 \\
\hline 3 & 9.5 & 1.5 & 9 & 2 & 5.5 & 5.5 & 2.5 & 8.5 \\
\hline 4 & 3 & 8 & 9 & 2 & 6 & 5 & 3 & 8 \\
\hline 5 & 3 & 8 & 3.5 & 7.5 & 8.5 & 2.5 & 3 & 8 \\
\hline 6 & 7 & 4 & 6.5 & 4.5 & 6 & 5 & 7.5 & 3.5 \\
\hline 7 & 3 & 8 & 2.5 & 8.5 & 6 & 5 & 6.5 & 4.5 \\
\hline 8 & 10 & 1 & 8 & 3 & 8.5 & 2.5 & 8 & 3 \\
\hline 9 & 9 & 2 & 4 & 7 & 6.5 & 4.5 & 2.5 & 8.5 \\
\hline 10 & 3.5 & 7.5 & 4 & 7 & 4.5 & 6.5 & 6.5 & 4.5 \\
\hline 11 & 5 & 6 & 3 & 8 & 4.5 & 6.5 & 3 & 8 \\
\hline 12 & 9.5 & 1.5 & 6 & 5 & 8 & 3 & 3.5 & 7.5 \\
\hline 13 & 9 & 2 & 3 & 8 & 9.5 & 1.5 & 4 & 7 \\
\hline 14 & 9.5 & 1.5 & 9.5 & 1.5 & 2.5 & 8.5 & 5.5 & 5.5 \\
\hline 15 & 3.5 & 7.5 & 9.5 & 1.5 & 7 & 4 & 6.5 & 4.5 \\
\hline 16 & 7 & 4 & 5 & 6 & 3 & 8 & 9.5 & 1.5 \\
\hline 17 & 5.5 & 5.5 & 3.5 & 7.5 & 5 & 6 & 2.5 & 8.5 \\
\hline 18 & 4.5 & 6.5 & 5 & 6 & 4.5 & 6.5 & 3.5 & 7.5 \\
\hline 19 & 10 & 1 & 5 & 6 & 9.5 & 1.5 & 10 & 1 \\
\hline 20 & 5.5 & 5.5 & 6.5 & 4.5 & 5.5 & 5.5 & 10 & 1 \\
\hline
\end{tabular}

After applying the FuzzyILS Questionnaire, it is high time to evaluate the dimensions with the fuzzy sets to know each degree of belonging of each dimension using Equation 1. Table 7 displays the evaluation of the learning style of the experimental groups. 
Table 7: Evaluation of learning styles using FuzzyILS sets

\begin{tabular}{|c|c|c|c|c|c|c|c|c|}
\hline Students & Sens. & Int. & Visual & Verb. & Seq. & Glob. & Act. & Refl. \\
\hline 1 & 0.69 & 0.44 & 1.00 & 0.00 & 0.94 & 0.19 & 0.56 & 0.56 \\
\hline 2 & 0.19 & 0.94 & 0.94 & 0.19 & 1.00 & 0.00 & 0.38 & 0.75 \\
\hline 3 & 1.00 & 0.06 & 1.00 & 0.13 & 0.56 & 0.56 & 0.19 & 0.94 \\
\hline 4 & 0.25 & 0.88 & 1.00 & 0.13 & 0.63 & 0.50 & 0.25 & 0.88 \\
\hline 5 & 0.25 & 0.88 & 0.31 & 0.81 & 0.94 & 0.19 & 0.25 & 0.88 \\
\hline 6 & 0.75 & 0.38 & 0.69 & 0.44 & 0.63 & 0.50 & 0.81 & 0.31 \\
\hline 7 & 0.25 & 0.88 & 0.19 & 0.94 & 0.63 & 0.50 & 0.69 & 0.44 \\
\hline 8 & 1.00 & 0.00 & 0.88 & 0.25 & 0.94 & 0.19 & 0.88 & 0.25 \\
\hline 9 & 1.00 & 0.13 & 0.38 & 0.75 & 0.69 & 0.44 & 0.19 & 0.94 \\
\hline 10 & 0.31 & 0.81 & 0.38 & 0.75 & 0.44 & 0.69 & 0.69 & 0.44 \\
\hline 11 & 0.50 & 0.63 & 0.25 & 0.88 & 0.44 & 0.69 & 0.25 & 0.88 \\
\hline 12 & 1.00 & 0.06 & 0.63 & 0.50 & 0.88 & 0.25 & 0.31 & 0.81 \\
\hline 13 & 1.00 & 0.13 & 0.25 & 0.88 & 1.00 & 0.06 & 0.38 & 0.75 \\
\hline 14 & 1.00 & 0.06 & 1.00 & 0.06 & 0.19 & 0.94 & 0.56 & 0.56 \\
\hline 15 & 0.31 & 0.81 & 1.00 & 0.06 & 0.75 & 0.38 & 0.69 & 0.44 \\
\hline 16 & 0.75 & 0.38 & 0.50 & 0.63 & 0.25 & 0.88 & 1.00 & 0.06 \\
\hline 17 & 0.56 & 0.56 & 0.31 & 0.81 & 0.50 & 0.63 & 0.19 & 0.94 \\
\hline 18 & 0.44 & 0.69 & 0.50 & 0.63 & 0.44 & 0.69 & 0.31 & 0.81 \\
\hline 19 & 1.00 & 0.00 & 0.50 & 0.63 & 1.00 & 0.06 & 1.00 & 0.00 \\
\hline 20 & 0.56 & 0.56 & 0.69 & 0.44 & 0.56 & 0.56 & 1.00 & 0.00 \\
\hline
\end{tabular}

\subsection{Evaluation of MOODLE Activities}

After evaluating learning styles, valuing the MOODLE activities with Equation 2 is necessary Table 8 shows the evaluation of the MOODLE activities in the FSLM dimensions for the first student. The MOODLE activities for all students are evaluated and their values are summarised in Table 9.

Table 8: Evaluation of the MOODLE activities in the FSLSM dimensions for the first student

\begin{tabular}{|c|c|c|c|c|c|c|c|c|c|}
\hline \multirow{2}{*}{$\begin{array}{l}\text { MOODLE } \\
\text { Activities }\end{array}$} & \multicolumn{9}{|c|}{ FSLSM Dimensions } \\
\hline & Sens. & Intui. & Visual & Verb. & \begin{tabular}{|l} 
Seq. \\
\end{tabular} & Glob. & Act. & Refl. & Tot. \\
\hline Forum & $2 * 0.69$ & $2 * 0.44$ & $0 * 1.00$ & $2 * 0.00$ & $2 * 0.94$ & $2 * 0.19$ & $2 * 0.56$ & $2 * 0.56$ & 6.76 \\
\hline Chat & $2 * 0.69$ & $0 * 0.44$ & $0 * 1.00$ & $2 * 0.00$ & $2 * 0.94$ & $0 * 0.19$ & $2 * 0.56$ & $0 * 0.56$ & 4.38 \\
\hline Gloss & $2 * 0.69$ & $0 * 0.44$ & $0 * 1.00$ & $2 * 0.00$ & $2 * 0.94$ & $0 * 0.19$ & $2^{*} 0.56$ & $0 * 0.56$ & 4.38 \\
\hline Workshop & $2 * 0.69$ & $2 * 0.44$ & $2 * 1.00$ & $2 * 0.00$ & $2 * 0.94$ & $2 * 0.19$ & $2 * 0.56$ & $2 * 0.56$ & 8.76 \\
\hline Survey & $2 * 0.69$ & $2 * 0.44$ & $2 * 1.00$ & $2 * 0.00$ & $0 * 0.94$ & $2 * 0.19$ & $2^{*} 0.56$ & $2 * 0.56$ & 6.88 \\
\hline Choice & $2 * 0.69$ & $0 * 0.44$ & $2 * 1.00$ & $2 * 0.00$ & $2 * 0.94$ & $1 * 0.19$ & $2^{*} 0.56$ & $0 * 0.56$ & 6.57 \\
\hline & $2 * 0.53$ & $1 * 0.59$ & $2 * 0.31$ & $2 * 0.81$ & $2 * 0.31$ & $1^{*} 0.81$ & $2 * 0.53$ & $1 * 0.59$ & 6.16 \\
\hline Wiki & $0 * 0.53$ & $2 * 0.59$ & $0 * 0.31$ & $2 * 0.81$ & $2 * 0.31$ & $0 * 0.81$ & $0 * 0.53$ & $2 * 0.59$ & 4.60 \\
\hline
\end{tabular}


Table 9: Evaluation of the MOODLE activities in the experimental group

\begin{tabular}{|c|c|c|c|c|c|c|c|c|}
\hline Est. & Forum & Chat & Glossary & Workshop & Survey & Choice & Lesson & Wiki \\
\hline 1 & 6.76 & 4.38 & 4.38 & 8.76 & 6.88 & 6.57 & 6.16 & 4.60 \\
\hline 2 & 6.88 & 3.50 & 3.50 & 8.75 & 6.13 & 6.88 & 6.81 & 5.75 \\
\hline 3 & 6.88 & 3.75 & 4.88 & 8.88 & 6.50 & 8.19 & 8.25 & 2.81 \\
\hline 4 & 7.00 & 2.50 & 3.50 & 9.00 & 6.50 & 6.75 & 7.50 & 4.63 \\
\hline 5 & 8.38 & 4.50 & 4.88 & 9.00 & 7.88 & 7.06 & 7.19 & 6.63 \\
\hline 6 & 7.63 & 5.25 & 6.25 & 9.00 & 6.00 & 7.75 & 8.00 & 4.81 \\
\hline 7 & 8.63 & 5.00 & 6.00 & 9.00 & 7.25 & 6.75 & 7.50 & 6.69 \\
\hline 8 & 7.00 & 6.13 & 6.50 & 8.75 & 5.25 & 8.56 & 7.81 & 4.38 \\
\hline 9 & 8.25 & 5.25 & 6.13 & 9.00 & 7.88 & 8.31 & 8.19 & 4.44 \\
\hline 10 & 8.25 & 4.38 & 5.75 & 9.00 & 6.88 & 6.69 & 7.75 & 5.81 \\
\hline 11 & 8.50 & 4.13 & 5.50 & 9.00 & 8.00 & 7.06 & 7.94 & 5.25 \\
\hline 12 & 7.63 & 5.38 & 5.88 & 8.88 & 7.00 & 8.50 & 7.94 & 4.31 \\
\hline 13 & 8.38 & 6.50 & 6.63 & 8.88 & 7.63 & 8.56 & 7.75 & 5.50 \\
\hline 14 & 6.75 & 3.63 & 5.50 & 8.75 & 5.63 & 7.69 & 8.50 & 2.31 \\
\hline 15 & 6.88 & 3.63 & 4.38 & 8.88 & 5.50 & 6.88 & 7.31 & 5.06 \\
\hline 16 & 7.88 & 5.25 & 7.00 & 8.88 & 5.88 & 7.25 & 8.25 & 4.56 \\
\hline 17 & 8.38 & 4.13 & 5.38 & 9.00 & 8.00 & 7.25 & 7.94 & 5.06 \\
\hline 18 & 8.00 & 3.63 & 5.00 & 9.00 & 7.38 & 6.94 & 7.88 & 4.94 \\
\hline 19 & 7.38 & 7.25 & 7.38 & 8.38 & 5.38 & 8.31 & 7.38 & 5.25 \\
\hline 20 & 7.38 & 5.13 & 6.25 & 8.75 & 5.38 & 7.06 & 7.63 & 5.13 \\
\hline
\end{tabular}

Figure 6 shows the three best activities for the experimental group.

\begin{tabular}{|c|c|c|c|}
\hline \multicolumn{4}{|c|}{ Evaluation of activities for each student } \\
\hline Student & Activity 1 & Activity 2 & Activity 3 \\
\hline 1 & Workshop & Choice & Lesson \\
\hline 2 & Forum & Workshop & Choice \\
\hline 3 & Workshop & Choice & Lesson \\
\hline 4 & Forum & Workshop & Lesson \\
\hline 5 & Forum & Workshop & Survey \\
\hline 6 & Workshop & Choice & Lesson \\
\hline 7 & Forum & Workshop & Lesson \\
\hline 8 & Workshop & Choice & Lesson \\
\hline 9 & Forum & Workshop & Choice \\
\hline 10 & Forum & Workshop & Lesson \\
\hline 11 & Forum & Workshop & Lesson \\
\hline 12 & Workshop & Choice & Lesson \\
\hline 13 & Forum & Workshop & Choice \\
\hline 14 & Workshop & Choice & Lesson \\
\hline 15 & Forum & Workshop & Lesson \\
\hline 16 & Forum & Workshop & Lesson \\
\hline 17 & Forum & Workshop & Survey \\
\hline 18 & Workshop & Choice & Lesson \\
\hline 19 & Forum & Workshop & Lesson \\
\hline 20 & Workshop & Choice & Lesson \\
\hline
\end{tabular}

Figure 6: Evaluation of MOODLE activities according to the learning styles of the experimental group

After the evaluation, there are many coincidences in the most appropriate MOODLE activities. Figure 7 displays the intersections and numbers of students in these intersections. 


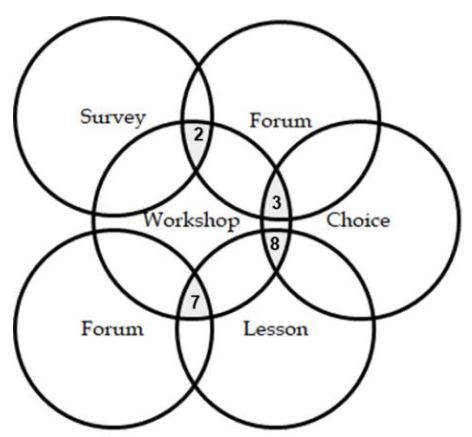

Figure 7: The intersection of MOODLE activities, evaluated in the experimental group

For the twenty students of the experimental group, the best MOODLE activities, according to their learning styles, are: Lesson, Workshop, Choice and Survey; for eight students are: Workshop, Choice, and Lesson; for seven Forum, Workshop and Lesson; for three students Forum, Workshop and Choice and finally for two students are: Forum, Workshop, and Survey.

\subsection{Present test and the evaluation of participation}

A face-to-face testis designed, along with analyzing students' participation in MOODLE activities. Table 10 reflects the obtained data.

Table 10: Participation of the students in the MOODLE activities and grade of the present test of the experimental group

\begin{tabular}{|c|c|c|c|c|c|c|}
\hline \multirow{2}{*}{ Est. } & \multicolumn{7}{|l|}{ Participation in MOODLE Activities } & & \\
\cline { 2 - 5 } & Forum & Workshop & Choice & Lesson & Participation Mean & Grade \\
\hline 1 & $85 \%$ & $100 \%$ & $100 \%$ & $100 \%$ & $96 \%$ & 19 \\
\hline 2 & $60 \%$ & $95 \%$ & $100 \%$ & $85 \%$ & $85 \%$ & 19 \\
\hline 3 & $50 \%$ & $100 \%$ & $100 \%$ & $90 \%$ & $85 \%$ & 19 \\
\hline 4 & $25 \%$ & $75 \%$ & $100 \%$ & $100 \%$ & $75 \%$ & 18 \\
\hline 5 & $10 \%$ & $0 \%$ & $0 \%$ & $50 \%$ & $15 \%$ & 8 \\
\hline 6 & $25 \%$ & $80 \%$ & $100 \%$ & $100 \%$ & $76 \%$ & 17 \\
\hline 7 & $33 \%$ & $100 \%$ & $100 \%$ & $75 \%$ & $77 \%$ & 18 \\
\hline 8 & $50 \%$ & $60 \%$ & $100 \%$ & $100 \%$ & $78 \%$ & 18 \\
\hline 9 & $33 \%$ & $100 \%$ & $100 \%$ & $100 \%$ & $83 \%$ & 19 \\
\hline 10 & $50 \%$ & $85 \%$ & $0 \%$ & $100 \%$ & $59 \%$ & 19 \\
\hline 11 & $75 \%$ & $100 \%$ & $0 \%$ & $75 \%$ & $63 \%$ & 18 \\
\hline 12 & $0 \%$ & $25 \%$ & $0 \%$ & $50 \%$ & $19 \%$ & 10 \\
\hline 13 & $100 \%$ & $80 \%$ & $100 \%$ & $100 \%$ & $95 \%$ & 19 \\
\hline 14 & $100 \%$ & $100 \%$ & $100 \%$ & $100 \%$ & $100 \%$ & 18 \\
\hline 15 & $25 \%$ & $100 \%$ & $100 \%$ & $75 \%$ & $75 \%$ & 19 \\
\hline 16 & $50 \%$ & $95 \%$ & $0 \% \%$ & $100 \%$ & $82 \%$ & 17 \\
\hline 17 & $75 \%$ & $100 \%$ & $100 \%$ & $100 \%$ & $94 \%$ & 19 \\
\hline 18 & $75 \%$ & $80 \%$ & $100 \%$ & $100 \%$ & $89 \%$ & 18 \\
\hline 19 & $75 \%$ & $100 \%$ & $100 \%$ & $100 \%$ & $94 \%$ & 18 \\
\hline 20 & $60 \%$ & $75 \%$ & $100 \%$ & $75 \%$ & $78 \%$ & 16 \\
\hline Mean & $\mathbf{5 2 . 8} \%$ & $\mathbf{8 2 . 5} \%$ & $\mathbf{7 5} \%$ & $\mathbf{8 8 . 7 5} \%$ & $\mathbf{7 5} \%$ & $\mathbf{1 7 . 3}$ \\
\hline
\end{tabular}

The MOODLE activity that most participants participate in is the Lesson, while the Forum is the lea stone. The mean of participation is $75 \%$. The mean of the grade is 17.3 , where the scale is $0-20$. The results are shown in Table 11. 
Table 11: Participation of students in MOODLE activities \& grade of the control group

\begin{tabular}{|c|c|c|c|c|c|c|}
\hline \multirow{2}{*}{ Est. } & \multicolumn{7}{|c|}{ Participation in MOODLE Activities } & & \\
\cline { 2 - 5 } & Forum & Workshop & Choice & Lesson & Activities Mean & Grade \\
\hline 1 & $100 \%$ & $100 \%$ & $100 \%$ & $75 \%$ & $94 \%$ & 15 \\
\hline 2 & $0 \%$ & $0 \%$ & $0 \%$ & $80 \%$ & $20 \%$ & 12 \\
\hline 3 & $50 \%$ & $85 \%$ & $0 \%$ & $75 \%$ & $53 \%$ & 18 \\
\hline 4 & $0 \%$ & $100 \%$ & $0 \%$ & $80 \%$ & $45 \%$ & 16 \\
\hline 5 & $10 \%$ & $80 \%$ & $100 \%$ & $70 \%$ & $65 \%$ & 14 \\
\hline 6 & $25 \%$ & $100 \%$ & $0 \%$ & $75 \%$ & $50 \%$ & 13 \\
\hline 7 & $0 \%$ & $75 \%$ & $0 \%$ & $50 \%$ & $31 \%$ & 15 \\
\hline 8 & $20 \%$ & $80 \%$ & $100 \%$ & $50 \%$ & $63 \%$ & 18 \\
\hline 9 & $50 \%$ & $80 \%$ & $100 \%$ & $100 \%$ & $83 \%$ & 18 \\
\hline 10 & $75 \%$ & $25 \%$ & $100 \%$ & $75 \%$ & $69 \%$ & 17 \\
\hline 11 & $15 \%$ & $75 \%$ & $100 \%$ & $100 \%$ & $73 \%$ & 20 \\
\hline 12 & $0 \%$ & $25 \%$ & $100 \%$ & $80 \%$ & $51 \%$ & 18 \\
\hline 13 & $0 \%$ & $75 \%$ & $0 \%$ & $50 \%$ & $31 \%$ & 13 \\
\hline 14 & $0 \%$ & $80 \%$ & $0 \%$ & $50 \%$ & $33 \%$ & 16 \\
\hline 15 & $100 \%$ & $50 \%$ & $0 \%$ & $100 \%$ & $63 \%$ & 17 \\
\hline 16 & $75 \%$ & $75 \%$ & $100 \%$ & $100 \%$ & $88 \%$ & 15 \\
\hline 17 & $100 \%$ & $75 \%$ & $100 \%$ & $100 \%$ & $94 \%$ & 17 \\
\hline 18 & $50 \%$ & $100 \%$ & $100 \%$ & $75 \%$ & $81 \%$ & 15 \\
\hline 19 & $100 \%$ & $50 \%$ & $100 \%$ & $80 \%$ & $83 \%$ & 18 \\
\hline 20 & $25 \%$ & $25 \%$ & $100 \%$ & $60 \%$ & $53 \%$ & 17 \\
\hline Mean & $\mathbf{3 9 . 7 5} \%$ & $\mathbf{6 8} \%$ & $\mathbf{6 0} \%$ & $\mathbf{7 6} \%$ & $\mathbf{6 8 \%} \%$ & $\mathbf{1 6 . 1}$ \\
\hline
\end{tabular}

Similar to the experimental group, in the control group, the MOODLE activity with most participation was the Lesson, and the least was the Forum. The mean of participation was $68 \%$. The mean of the grade was 16.1, where the scale was 020. Figure 8 shows the participation comparative of the two groups. Figure 9 shows the grade of the face-to-face test of the two groups.

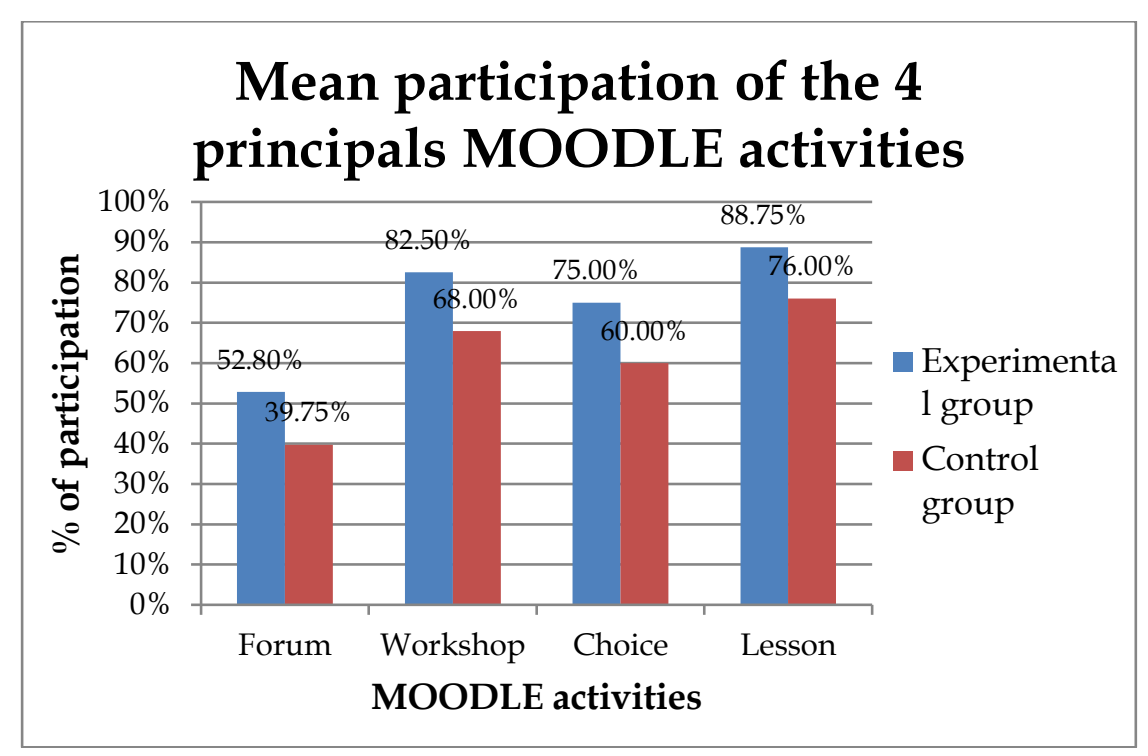

Figure 8: ComparingParticipants' Participantion in Both Groups 
Participation in all MOODLE activities was greater in the experimental group than in the control group. Also, the mean grade of the face-to-face test was greater in the experimental group than the control group, showed in Figure 9.

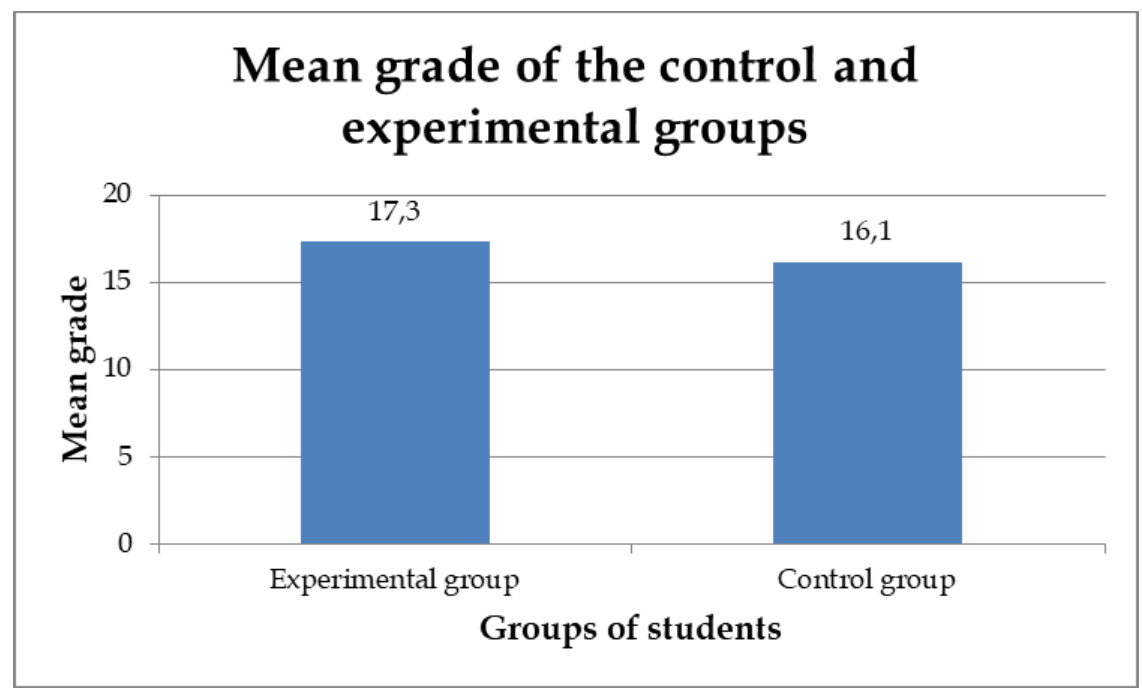

Figure 9: Grade of the face-to-face test of the two groups

\section{Results}

In the experimental group, the MOODLE activity with most participation was the Lesson, and with the least was the Forum. The participation mean was $75 \%$, and the mean of the grade was 17.3/20. The correlation between the participation of students and their grades, results in a strong positive correlation of the variables $(\mathrm{r}=0.86)$, and the value of the coefficient of determination is $\left(\mathrm{r}^{2}\right)=$ 0.75 . This coefficient is the common variability between both variables. Figure 10 shows and explains the correlation.

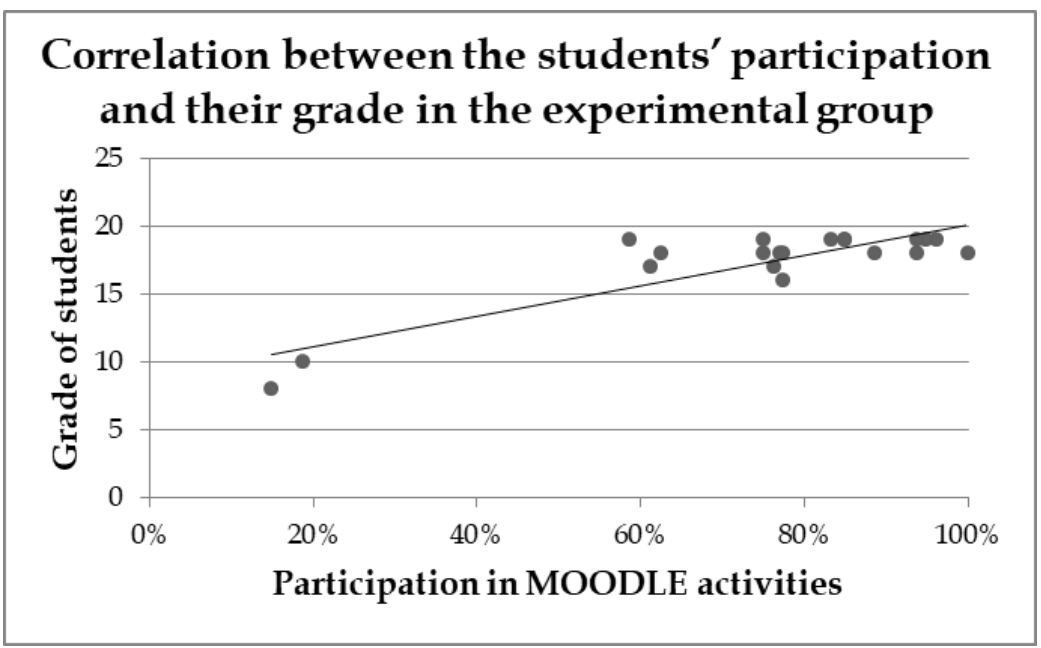

Figure 10: Correlation between the students' participation and their grade in the experimental group

Similar to the experimental group, in the control group, the MOODLE activity with most participation was the Lesson, and the least was the Forum. The participation mean was $68 \%$. The mean of the grade was $16.1 / 20$. The correlation 
between the student's participation and their grades was $r=0.41$, which indicates a weak positive correlation of the variables. The value of the coefficient of determination $\left(\mathrm{r}^{2}\right)=0.17$. This coefficient is the common variability between both variables. Figure 11 summarises these data.

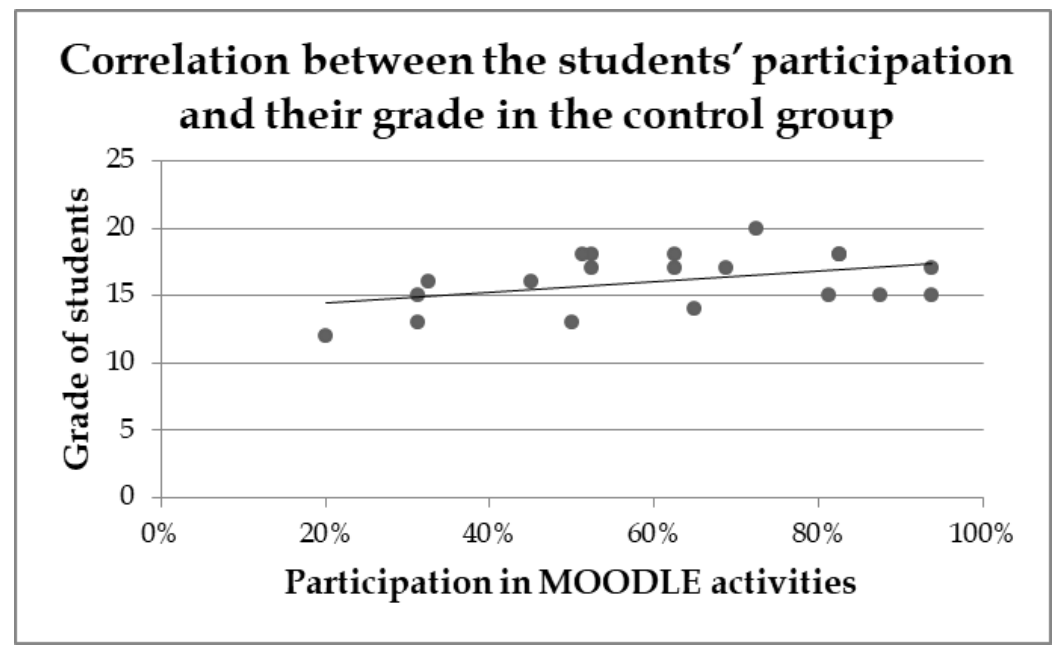

Figure 11: Correlation between the students' participation and their grade in the control group

\section{Conclusion}

In this research paper, the FuzzyILS Method is incorporated into MOODLE as a starting point to the previous proposals of other researchers (Borga, 2009; Puello, Fernandez \& Cabarcas, 2014), who added the Learning styles Test into the LMS. The MOODLE Database is modified unlike to the previous existing proposals wherein new programs are created to assess degrees of membership in the fuzzy sets and to evaluate MOODLE activities with the FuzzyILS Method. In the experimentation, the Glossary, Chat, and Wiki activities were poorly evaluated in all cases in the sense that they were not selected among the first four MOODLE activities. Prince (2013), and Freeman and his colleagues (Freeman et al., 2014) affirm that students learn and perform better if the learning environment includes activities in which they participate and apply knowledge, rather than being passive in the process and simply listening. The results of the experimental group show evidence that when MOODLE is used, students use appropriate techniques learning styles, participate more in the activities, and obtain better grades. As far as the latter is concerned, students achieve good grades owing to their understanding of the content delivered and the participation they perform (Prince, 2013; Freeman et al., 2014). A strong positive correlation and a great coefficient of determination are met in the experimental group. Meanwhile, weak positive correlations along with students' grades are less with the control group. Hence, it is safe to mention that the intervention brought interesting results and the hybridization process the present paper suggests is workable for effective course and meeting urgent needs. Further attempts need to cover large population in different contexts to collect evidences to elaborate references on this issue. 


\section{References}

Almeida, G., Romero, W., \& Arce, A. (2017). MOODLE una contribución para elevar la calidad del proceso de enseñanza-aprendizaje [MOODLE a contribution to raise the quality of the teaching-learning process]. Retrieved from http://www.eumed.net/rev/atlante/2017/10/Moodle-ensenanzaaprendizaje.html

Artopoulos, A. (2020). COVID-19: ¿Qué hicieron los países para continuar con la educación a distancia? [COVID-19: What did countries do to continue distance education?]. Revista Latinoamericana de Educación Comparada, 11(17), 1-11. Retrieved from http://www.saece.com.ar/relec/revistas/17/doc2.pdf

Bignetti, J., \& Jasbinschek, C. (2011, August 30-September 02). Estilos de aprendizagem e interfaces adaptativas em ambientes virtuais baseados na plataforma MOODLE [Learning styles and adaptive interfaces in virtual environments based on the MOODLE platform]. Conference proceedings of the $17^{\circ}$ congresso internacional de educação a distância. Manaus. Amazonas, Brasil. Retrieved from http://www.abed.org.br/congresso2011/cd/250.pdf

Boneu, J. M. (2007). Plataformas abiertas de e-learning para el soporte de contenidos educativos abiertos [Open e-learning platforms to support open educational content]. Revista de Universidad y Sociedad del Conocimiento (RUSC), 4(1), 36-46. http://dx.doi.org/10.7238/rusc.v4i1.298

Cabero-Almenara, J., Arancibia, M., \& del Prete, A. (2019). Technical and Didactic Knowledge of the Moodle LMS in Higher Education. Beyond Functional Use. Journal of New Approaches in Educational Research (NAER Journal), 8(1), 25-33. https:// doi.org/10.7821/naer.2019.1.327

Cataldi, Z., Figueroa, N., Méndez, P., Lage, F., Vigliecca, M., \& Kraus, G. (2006). Herramienta automatizada para la determinación de los estilos en ingresantes cursos de programaciónbásica de aprendizaje [Automated tool for determining styles in incoming basic learning programming courses]. Conference proceedings of the XII Congreso Argentino en Ciencias de la Computación. Retrieved from http://sedici.unlp.edu.ar/handle/10915/22529

Despotović-Zrakić, M., Marković. A., Bogdanović, Z., Barać, D., \& Krčo, S. (2012). Providing adaptivity in MOODLE LMS Courses. Educational Technology $\mathcal{E}$ Society, 15(1), 326-338. Retrieved from www.jstor.org/stable/jeductechsoci.15.1.326

Díaz, S. (2009). Introducción a las Plataformas Virtuales en la Enseñanza [Introduction to Virtual Platforms in Teaching]. Temas para la educación, 2, 1-7. Retrieved from https://www.feandalucia.ccoo.es/docuipdf.aspx?d=4920\&s=

Díaz-Barriga, F., \& Hernández, G. (2010). Teaching strategies for meaningful learning (3 ${ }^{\text {rd }}$ ed.). McGraw-HILL: México.

Dorfsmani, M. (2012). La profesión docente en contextos de cambio: El docente global en la Sociedad de la Información [The teaching profession in contexts of change: The global teacher in the Information Society]. RED - Docencia Universitaria en la Sociedad del Conocimiento - Universidad de Murcia,6, 1-23. Retrieved from http://www.um.es/ead/reddusc/6/marcelo_dusc6.pdf

Felder, R., \& Silverman, L. (1988). Learning and Teaching Styles in Engineering Education, Engr. Education, 78(7), 674-681. Retrieved from http://www4.ncsu.edu/unity/lockers/users/f/felder/public/Papers/LS1988.pdf.

Felder, R., \& Soloman, B. (2007). Index of Learning styles [Blog post]. Retrieved from http://www.engr.ncsu.edu/learningstyles/ilsweb.html. 
Freeman, S., Eddya, S., McDonougha, M., Smithb, M., Okoroafora, N., Jordta, H., \& Pat Wenderotha, M. (2014). Active learning increases student performance in science, engineering, and mathematics. Proceedings of the National Academy of Sciences, 111(23), 8410 -8415. DOI: 10.1073/pnas.1319030111

Graf, S., \& Kinshuk, K. (2007). Providing Adaptive Courses in Learning Management Systems with Respect to Learning styles. In T. Bastiaens \& S. Carliner (Eds.), Proceedings of the World Conference on E-Learning in Corporate, Government, Healthcare, and Higher Education. Quebec City, Canada. Retrieved from https://www.learntechlib.org/primary/p/26739/

Graf, S., Kinshuk, K., \& Liu, T. (2008). Identifying Learning Styles in Learning Management Systems by Using Indications from Students' Behaviour. Paper presented at the 2008 eighth IEEE international conference on advanced learning technologies. https://doi.org/10.1109/ICALT.2008.84

Karagiannis, I., \& Satratzemi, M. (2018). An adaptive mechanism for Moodle based on automatic detection of learning styles. Education and Information Technologies, 23, 1331-1357. https://doi.org/10.1007/s10639-017-9663-5

Keefe, J. W. (1987). Learning Style Theory and Practice. National Association of Secondary School Principals. Reston, VA, USA.

Lavigne, G., Díaz, K., McAnally, L., \& Organista, J. (2013). Navegar y aprender: una aproximación a las relaciones entre estilos de aprendizaje y la navegación en MOODLE [Navigating and learning: an approach to the relationships between learning styles and navigation in MOODLE]. Universities and Knowledge Society Journal, 10(2), 81-97. http:// dx.doi.org/10.7238/rusc.v10i2.1402

Lozano, S., Suescún, E., Vallejo, P., Mazo, R., \& Correa D. (2020). Comparando dos estrategias de aprendizaje activo para enseñar Scrum en un curso introductorio de ingeniería de software [Comparing two active learning strategies for teaching Scrum in an introductory software engineering course]. Ingeniare, Revista Chilena de Ingeniería, 28(1), 83-94. http://dx.doi.org/10.4067/S0718-33052020000100083

Mohd, F., Yahya, W. F. F., Ismail, S., Jalil, M. A., \& Noor, N. M. M. (2019). An Architecture of Decision Support System for Visual-Auditory-Kinesthetic (VAK) Learning styles Detection Through Behavioral Modelling. International Journal of Innovation in Enterprise System, 3(2), 24-30. http://dx.doi.org/10.25124/ijies.v3i02.37

Moodle. (2020). Retrieved from https://docs.Moodle.org/38/en/Activities

Ossandón, Y., \& Castillo, P. (2006). Propuesta para el Diseño de Objetos de Aprendizaje [Proposal for the Design of Learning Objects]. Revista Facultad de Ingeniería. Universidad del Tarapacá, 14(1), 36-48. Retrieved from http:/ / www.scielo.cl/scielo.php?pid=S071813372006000100005\&script=sci_arttext

Pacheco, J., Miranda, Y., \& Alonso, R. (2020, March 16-20). Adaptación de un aula virtual en Moodle a los estilos de aprendizaje [Adaptation of a virtual classroom in Moodle to learning styles]. Paper presented at the XVIII Congreso Internacional de Informática en la Educación INFOREDU, La Habana, Cuba. Retrieved from http://www.informaticahabana.cu/sites/default/files/ponencia2020/EDU077.pdf

Paredes, P. (2008). A Proposal for Incorporating Learning styles into User Models in Adaptive Teaching Systems (Doctoral dissertation, the Universidad Autónoma de Madrid. Departamento de Ingeniería Informática, Madrid, España). Retrieved from http://arantxa.ii.uam.es/ pparedes/tesis.pdf

Peña Estrella, N. F., Mendoza Moreno, M. A., \& González Serrano, C. (2015). Diagnóstico de estilos de aprendizaje para favorecer la personalización de materiales 
educativos mediante redes bayesianas: servicios web para MOODLE [Diagnosis of learning styles to favor the personalization of educational materials through Bayesian networks: web services for MOODLE]. Revista Virtual Universidad Católica del Norte,46, 4-20. Retrieved from https://revistavirtual.ucn.edu.co/index.php/RevistaUCN/article/view/694

Prince, M. (2013). Does active learning work? A review of the research. Journal of engineering education,93(3), 223-231. https://doi.org/10.1002/j.21689830.2004.tb00809.x

Puello, P., Fernández, D., \& Cabarcas, A. (2014). Herramienta para la detección de estilos de aprendizaje en estudiantes utilizando la plataforma MOODLE [Tool for detecting learning styles in students using the MOODLE platform]. Formación Universitaria, 7(4), 15-24. http:// dx.doi.org/10.4067/S0718-50062014000400003

Rubio, R. B. (2009). Nuevo módulo de test de estilos de aprendizaje [New learning styles test module]. MOODLE Forum. Retrieved from https://Moodle.org/mod/forum/discuss.php?d=140052

Szirmai, M. (2020). Moodle: The Ubiquitous Teacher. Electronic Journal of Foreign Language Teaching, 17(1), 190-204. https://doi.org/10.1007/978-1-4020-9732-4_12

Silva, S. A., Ponce, G. J., \& Meneses, H. J. (2013). Gestionando el Conocimiento en MOODLE [Managing Knowledge in MOODLE]. Proceedings of the VIII Conferencia Latino americana de Objetos de Aprendizaje y Tecnologías para el Aprendizaje (LACLO2013) (pp. 115-126). Valdivia, Chile.

Silva, S. A., Ponce, G. J., \& Villalpando, C. M. (2013). Hacia un Método Recomendador de Técnicas Instruccionales para el Desarrollo de Objetos de Aprendizaje [Towards a Recommending Method of Instructional Techniques for the Development of Learning Objects]. Proceedings of the VIII Conferencia Latinoamericana de Objetos de Aprendizaje y Tecnologías para el Aprendizaje (LACLO2013) (pp. 127-138). Valdivia, Chile.

Silva, S. A., Ponce, G. J., \& Villalpando, C. M. (2014). Development Model of Learning Objects Based on the Instructional Techniques Recommendation. International Journal of Learning. Teaching and Educational Research, 4(1), 27-35. Retrieved from http://www.ijlter.org/index.php/ijlter/article/view/42/pdf

Silva, S. A., Ponce, G. J., \& Villalpando, C. M. (2014a). Sistema Recomendador de Técnicas Instruccionales, Basado en Objetivos Pedagógicos - ReTIBO [Recommend System of Instructional Techniques, Based on Pedagogical Objectives - ReTIBO]. Revistavenezolana de educación (EDUCERE), 60, 281-287. Retrieved

from http://www.saber.ula.ve/bitstream/123456789/38892/1/articulo9.pdf

Silva, S. A., \& Ponce, G. J. (2015). Evaluación del Método para el Desarrollo de Objetos de Aprendizaje. basado en Estilos de Aprendizaje: MeLOTS [Evaluation of the Method for the Development of Learning Objects. Based on Learning styles: MeLOTS]. Revista Tecnológica ESPOL - RTE. Ecuador, 28(5), 39-53. Retrieved from http://rte.espol.edu.ec/index.php/tecnologica/article/view/424/290

Silva, S. A., \& Vicari, R. (2016). New Moodle Blocks for Knowledge Management. In F. Koch, A. Koster \& T. Primo (Eds), Social Computing in Digital Education. SOCIALEDU 2015. Communications in Computer and Information Science (pp. 104123). Springer, Cham. https://doi.org/10.1007/978-3-319-39672-9_8

Silva, S. A. (2018). Conceptualización de los Modelos de Estilos de Aprendizaje [Conceptualization of Learning Style Models]. Journal of Learning styles, 11(21), 133. Retrieved from http://revistaestilosdeaprendizaje.com/article/view/1088

Silva, S. A. (2020). Towards a Fuzzy Questionnaire of Felder and Soloman for determining learning styles without dichotomic in the answers. Journal of 
Learning styles, 13(15), 146-166. Retrieved from http://revistaestilosdeaprendizaje.com/article/view/1853

Torres, S., Molina, B., \& Álvarez, D. (2010). Integración de los Estilos de Aprendizaje en Moodle. para el Proyecto Guadalinfo [Integration of Learning styles in Moodle. for the Guadalinfo Project]. Proceedings of the I Congreso de Calidad de la Formación Virtual CAFVIR (pp. 413-418). Alcalá de Henares, España.

Zadeh, L. A. (1965). Fuzzy Sets. Information and control, 8, 338-353.

\section{Appendix}

\section{FuzzyILS Questionnaire}

Question 1, associated with the Active/Reflective dimension, "I understand something better after:"

a. Always practice

b. Almost always practice, and rarely reflect on them

c. Sometimes practice, and sometimes reflect on them

d. Almost always reflect on them, and rarely practice

e. Always reflect on them

Question 2, associated with the Sensing/Intuitive dimension, "I consider myself:"

a. Always realistic

b. Almost always realistic, and rarely innovative

c. Sometimes realistic, and sometimes innovative

d. Almost always innovative, and rarely realistic

e. Always innovative

Question 3, associated with the Visual/Verbal dimension, "When I think about what I did yesterday, I am more likely to do it based on:"
a. Always an image
b. Almost always an image, and rarely words
c. Sometimes an image, and sometimes words
d. Almost always words, and rarely an image
e. Always words

Question 4, associated with the Sequential/Global dimension, "I tend to:"

a. Always understand the details of a topic, but not see its complete structure

b. Almost always understand the details of a topic, but not see its complete structure, and rarely understand the complete structure, but not see the details

c. Sometimes understanding the details of a topic, but not seeing its complete structure, and other times understanding the complete structure, but not seeing the details

d. Almost always understand the complete structure, but not see the details, and rarely understand the details of a topic, but not see its complete structure

e. Always understand the complete structure, but not see the details.

Question 5, associated with the Active/Reflective dimension, "When I am learning something new, it helps me:"

a. Always talk about it

b. Almost always talk about it, and rarely think about it

c. Sometimes talk about it, and sometimes think about it

d. Almost always think about it, and rarely talk about it

e. Always think about it

Question 6, associated with the Sensing/Intuitive dimension, "If I were a teacher, I would prefer to give a course:"

a. Whenever it deals with facts and real-life situations

b. Almost always when dealing with real events and situations in life, and rarely dealing with ideas and theories 
c. Sometimes that deals with facts and real situations of life, and other times that deals with ideas and theories

d. Almost whenever he deals with ideas and theories, and rarely deals with facts and real-life situations

e. Whenever dealing with ideas and theories

Question 7, associated with the Visual/Verbal dimension, "I prefer to obtain new information:"

a. Always of images, diagrams, graphs or maps

b. Almost always of images, diagrams, graphs, or maps, and rarely of written instructions or verbal information

c. Sometimes of images, diagrams, graphs, or maps, and sometimes of written instructions or verbal information

d. Almost always written instructions or verbal information, and rare images, diagrams, graphs, or maps

e. Always written instructions or verbal information

Question 8, associated with the Sequential/Global dimension, "Once I understand:"

a. All parties, I always understand the total

b. All parties, I almost always understand the total, and when I understand the total of something, I rarely understand how their parts fit together

c. All parties, sometimes I understand the total, and when I understand the total of something, sometimes I understand how their parts fit together

d. The total of something, I almost always understand how its parts fit together, and when I understand all the parts, I rarely understand the total

e. The total of something, I always understand how its parts fit together

Question 9, associated with the Active/Reflective dimension, "In a study group that works with a difficult material, it is more likely that:"

a. Always participate and contribute ideas

b. Almost always participate and contribute ideas, and rarely do not participate and just listen

c. Sometimes participate and contribute ideas, and sometimes do not participate and just listen

d. Almost always do not participate and just listen, and rarely participate and contribute ideas

e. Never participate and just listen

Question 10, associated with the Sensing/Intuitive dimension, "It's easier for me:"

a. Always learn facts

b. Almost always learn facts, and rarely learn concepts

c. Sometimes learn facts, and sometimes learn concepts

d. Almost always learn concepts, and rarely learn facts

e. Always learn concepts

Question 11, associated with the Visual/Verbal dimension, "In a book with many images and graphics it is more likely that:"

a. Always check images and graphics carefully

b. I almost always carefully check the images and the graphics and rarely focus on the written text

c. Sometimes I carefully review the images and the graphics and other times I focus on the written text

d. I almost always concentrate on the written text, and rarely check the images and graphics carefully

e. Always concentrate on the written text

Question 12, associated with the Sequential/Global dimension, "When I solve math problems:"

a. I always work on solutions one step at a time 
b. I almost always work on solutions one step at a time and rarely know what the solutions are, but then I have difficulty imagining the steps to reach them

c. Sometimes I work on the solutions one step at a time and other times I know what the solutions are, but then I have difficulty imagining the steps to reach them

d. I almost always know what the solutions are, but then I have difficulty imagining the steps to reach them and I rarely work on the solutions one step at a time

e. I always know what the solutions are, but then I have difficulty imagining the steps to reach them

Question 13, associated with the Active/Reflective dimension, "In the classes, I have attended:"

a. I have usually come to know how many of the students are

b. Many times I have come to know how many of the students are

c. Sometimes I have come to know how many of the students are

d. I have rarely come to know how many of the students are

e. I have rarely come to know how many students are

Question 14, associated with the Sensing/Intuitive dimension, "When I read non-fiction topics, I prefer:"

a. Always something that teaches me new facts or tells me how to do something

b. Almost always something that teaches me new facts or tells me how to do something and rarely something that gives me new ideas to think about

c. Sometimes something that teaches me new facts or tells me how to do something and sometimes something that gives me new ideas to think about

d. Almost always something that gives me new ideas to think about, and rarely something that teaches me new facts or tells me how to do something

e. Always something that gives me new ideas to think about

Question 15, associated with the Visual/Verbal dimension, "I like teachers who:"

a. Always use many schemes on the board

b. They almost always use many schemes on the board, and rarely take much time to explain

c. Sometimes they use many schemes on the board, and sometimes they take a long time to explain

d. They almost always take a long time to explain, and rarely use many schemes on the board

e. They always take a long time to explain

Question 16, associated with the Sequential/Global dimension, "When I am analyzing a story or a novel:"

a. I always think about the incidents and try to accommodate them to configure the issues

b. I almost always think about the incidents and try to accommodate them to configure the issues, and rarely do I realize what the issues are when I finish reading, and then I have to go back and find the incidents that show them

c. Sometimes I think about the incidents and try to accommodate them to configure the topics, and other times I realize what the issues are when I finish reading and then I have to go back and find the incidents that show them

d. I almost always realize what the issues are when I finish reading and then I have to go back and find the incidents that demonstrate them, and I rarely think about the incidents and try to accommodate them to configure the topics

e. I realize what the issues are when I finish reading and then I have to go back and find the incidents that show them

Question 17, associated with the Active/Reflective dimension, "When I start solving a task problem, it is more likely that:" 
a. Always start working on your solution immediately

b. Almost always start working on your solution immediately, and rarely try first to fully understand the problem

c. Sometimes start working on your solution immediately, and other times try first to fully understand the problem

d. Almost always try first to fully understand the problem, and rarely start working on your solution immediately

e. Always try to fully understand the problem first

Question 18, associated with the Sensing/Intuitive dimension, "I prefer the idea of:"

a. Always certainty

b. Almost always a certainty, and rarely the theory

c. Sometimes certainty, and sometimes the theory

d. Almost always the theory, and rarely certainty

e. Always the theory

Question 19, associated with the Visual/Verbal dimension, "I remember better:"

a. Always what I see

b. Almost always what I see and rarely what I hear

c. Sometimes what I see and sometimes what I hear

d. Almost always what I hear and rarely what I see

e. Always what I hear

Question 20, associated with the Sequential/Global dimension, "It is more important to me than a teacher:"

a. Always expose the material in clear sequential steps

b. I almost always expose the material in clear sequential steps, and rarely give me an overview and relate the material to other topics

c. Sometimes exposing the material in clear sequential steps, and sometimes give me an overview and relate the material to other topics

d. Almost always give me an overview and relate the material to other topics, and rarely expose the material in clear sequential steps

e. Always give me an overview and relate the material to other topics

Question 21, associated with the Active/Reflective dimension, "I prefer to study:"

a. Always in a study group

b. Almost always in a study group, and rarely alone

c. Sometimes in a study group, and sometimes only

d. Almost always alone, and rarely in a study group

e. Always alone

Question 22, associated with the Sensing/Intuitive dimension, "I consider myself:"

a. Always careful in the details of my work

b. Almost always careful in the details of my work and rarely creative in the way I do my work

c. Sometimes careful in the details of my work and sometimes creative in the way I do my work

d. Almost always creative in the way I do my work and rarely careful in the details of my work

e. Creative in the way I do my job

Question 23, associated with the Visual/Verbal dimension, "When someone gives me directions to new places, I prefer:"

a. Always a map

b. Almost always a map and rarely written instructions

c. Sometimes a map and sometimes written instructions

d. Almost times written instructions, and rarely a map

e. Always written instructions

Question 24, associated with the Sequential/Global dimension, "I learn:" 
a. Always at a constant pace. If I study hard I get what I want

b. Almost always at a constant pace. If I study hard I get what I want, and rarely in the beginning and pauses. I get confused and suddenly I understand

c. Sometimes at a constant pace. If I study hard I get what I want, and other times in the beginning and pauses. I get confused and suddenly I understand

d. Almost always in the beginning and pauses. I get confused and suddenly I understand, and rarely at a constant pace. If I study hard I get what I want

e. Always at the beginning and pauses. I get confused and suddenly I understand Question 25, associated with the Active/Reflective dimension, "I prefer first:"

a. Always do something and see what happens

b. I almost always do something and see what happens, and rarely think about how I am going to do something

c. Sometimes do something and see what happens, and sometimes think about how I am going to do something

d. I almost always think about how I am going to do something, and rarely do something and see what happens

e. Always think about how I'm going to do something

Question 26, associated with the Sensing/Intuitive dimension, "When I read for fun, I like writers who:"

a. They always say clearly what they want to imply

b. They almost always say clearly what they want to imply, and rarely say things creatively and interestingly

c. Sometimes they say clearly what they want to imply, and other times they say things creatively and interestingly

d. They almost always say things creatively and interestingly, and rarely say clearly what they want to imply

e. They always say things creatively and interestingly

Question 27, associated with the Visual/Verbal dimension, "When I see a scheme or outline in class, I am more likely to remember:"

a. Always the image

b. Almost always the image and rarely what the professor said about it

c. Sometimes the image and sometimes what the professor said about it

d. Almost always what the professor said about her, and rarely the image

e. Always what the teacher said about her

Question 28, associated with the Sequential/Global dimension, "When I face an information body:"

a. I always concentrate on the details and lose sight of the total

b. I almost always concentrate on the details and lose sight of the total, and rarely try to understand the whole before going to the details

c. Sometimes I focus on the details and lose sight of the total, and other times I try to understand the whole before going to the details

d. I almost always try to understand the whole before going to the details, and rarely do I focus on the details and lose sight of the total of it

e. I always try to understand the whole before going to the details

Question 29, associated with the Active/Reflective dimension, "I remember more easily:"

a. Always something I have done

b. Almost always something I've done, and rarely something I've thought about a lot

c. Sometimes something I've done, and sometimes something I've thought about a lot

d. Almost always something I've thought about a lot, and rarely something I've done

e. Always something I've thought about a lot 
Question 30, associated with the Sensing/Intuitive dimension, "When I have to do a job, I prefer:"

a. Always master a way of doing it

b. Almost always master a way of doing it, and rarely try new ways to do it

c. Sometimes master a way of doing it, and sometimes try new ways to do it

d. Almost always try new ways to do it, and rarely master a way to do it

e. Always try new ways to do it

Question 31, associated with the Visual/Verbal dimension, "When someone teaches me data, I prefer:"

a. Always graphics

b. Almost always graphics, and rarely summaries with text

c. Sometimes graphics, and sometimes summaries with text

d. Almost always summaries with text, and rarely graphics

e. Always summaries with text

Question 32, associated with the Sequential/Global dimension, "When I write a paper, I am more likely to do it (think or write):"

a. Always from the beginning and advance

b. Almost always from the beginning and advance, and rarely in different parts and then order them

c. Sometimes from the beginning and advance, and sometimes in different parts and then order them

d. Almost always in different parts and then order them, and rarely from the beginning and advance

e. Always in different parts and then order them

Question 33, associated with the Active/ Reflective dimension, "When I have to work on a group project, I first want to do:"

a. Always a "brainstorm" where everyone contributes ideas

b. Almost always a "brainstorm" where everyone contributes ideas, and rarely the "brainstorm" personally and then join the group to compare ideas

c. Sometimes a "brainstorm" where everyone contributes ideas, and sometimes the "brainstorm" personally and then join the group to compare ideas

d. Almost always the "brainstorm" personally and then join the group to compare ideas, and rarely a "brainstorm" where everyone contributes ideas

e. Always "brainstorm" personally and then join the group to compare the ideas Question 34, associated with the Sensing/Intuitive dimension, "I consider:"

a. Whenever it is better to praise to call someone Sensing

b. Almost always it is better to praise calling someone Sensing, and rarely is it better to call it imaginative

c. Sometimes it is better to praise to call someone Sensing, and other times to call it imaginative

d. Almost always it is better to praise calling someone imaginative, and rarely calling him Sensing

e. Whenever it is better to praise to call someone imaginative

Question 35, associated with the Visual/Verbal dimension, "When I meet people at a party, I am more likely to remember:"

a. Always their appearance

b. Almost always their appearance, and rarely what they say about themselves

c. Sometimes what their appearance looks like, and sometimes what they say about themselves

d. Almost always what they say about themselves, and rarely how is their appearance

e. Always what they say about themselves 
Question 36, associated with the Sequential/Global dimension, "When I am learning a subject, I prefer:"

a. Always stay focused on that topic, learning as much as I can from him

b. I almost always stay focused on that topic, learning as much as I can from it, and rarely make connections between that topic and related topics

c. Sometimes I stay focused on that topic, learning as much as I can from it, and other times make connections between that topic and related topics

d. I almost always make connections between that topic and related topics, and rarely stay focused on that topic, learning as much as I can from it

e. Always make connections between that topic and related topics

Question 37, associated with the Active/Reflective dimension, "I consider myself:"

a. Always open

b. Almost always open, and rarely reserved

c. Sometimes open, and sometimes reserved

d. Almost always reserved, and rarely open

e. Always reserved

Question 38, associated with the Sensing/Intuitive dimension, "I prefer courses that give more importance to:"

a. Always concrete material (facts, data)

b. Almost always concrete material (facts, data), and rarely abstract material (concepts, theories)

c. Sometimes concrete material (facts, data), and sometimes abstract material (concepts, theories)

d. Almost always abstract material (concepts, theories), and rarely concrete material (facts, data)

e. Always abstract material (concepts, theories)

Question 39, associated with the Visual/Verbal dimension, "To have fun, I prefer:"

a. Always watch television

b. Almost always watch television, and rarely read a book

c. Sometimes watching television, and sometimes reading a book

d. Almost always read a book, and rarely watch television

e. Always read a book

Question 40, associated with the Sequential/Global dimension, "Some teachers start their classes by outlining what they will teach. Those sketches are: "

a. Always something useful for me

b. Almost always something useful, and rarely very useful for me

c. Sometimes something useful, and sometimes very useful for me

d. Almost always very useful, and rarely useful for me

e. Always very useful for me

Question 41, associated with the Active/Reflective dimension, "The idea of doing a group task with only one qualification for all:"

a. It always seems good to me

b. It almost always seems good to me, and rarely

c. Sometimes it seems good to me, and sometimes it doesn't

d. It almost never seems good to me and rarely does it

e. It never seems good to me

Question 42, associated with the Sensing/Intuitive dimension, "When I do large calculations:"

a. I always tend to repeat all my steps and check carefully

b. I almost always tend to repeat all my steps and carefully review my work, and rarely do I get tired of doing their review and I have to make an effort to do it

c. Sometimes I tend to repeat all my steps and carefully review my work, and other times I get tired of doing its review and I have to make an effort to do it 
d. I almost always tend to repeat all my steps and carefully review my work, and rarely do I tend to repeat all my steps and carefully review my work

e. I always get tired of doing his review and I have to make an effort to do it Question 43, associated with the Visual/Verbal dimension, "I tend to remember places where I have been:"

a. Always easily and quite accurately

b. Almost always easily and quite accurately, and rarely with difficulty and without much detail

c. Sometimes easily and quite accurately, and sometimes with difficulty and without much detail

d. Almost always easily and fairly accurately, and rarely easily and fairly accurately

e. Always with difficulty and without much detail

Question 44, associated with the Sequential/Global dimension, "When I solve problems in a group, it is more likely that I:"

a. Always think of the steps to solve problems

b. Almost always think about the steps for solving problems, and rarely think about the possible consequences or applications of the solution in a wide range of fields

c. Sometimes think about the steps to solve the problems, and sometimes think about the possible consequences or applications of the solution in a wide range of fields

d. Almost always think about the possible consequences or applications of the solution in a wide range of fields, and rarely think about the steps to solve the problems

e. Always think about the possible consequences or applications of the solution in a wide range of fields 